\title{
Endoparasites of the Long-Eared Hedgehog (Hemiechinus auritus) in Zabol District, Southeast Iran
}

\author{
İran'ın Güneydoğusunda bulunan Zabol'da Uzun Kulaklı Kirpilerde (Hemiechinus Auritus)
} Görülen Endoparazitler

\section{Nafiseh Zolfaghari, Reza Nabavi}

University of Zabol, Veterinary Medicine, Zabol, Iran

\section{ABSTRACT}

Objective: The long-eared hedgehog (Hemiechinus auritus) is a nocturnal animal living in Central and Southeast Iran. However, there are few studies concerning endoparasites, some of which are zoonotic, of the hedgehogs in the north and northwest of Iran. The aim of the present study is to investigate endoparasites in long-eared hedgehogs, living in Zabol district, Southeast Iran.

Materials and Methods: Stool and blood samples collected from 50 hedgehogs (35 males and 15 females) that were trapped alive were examined with Clayton-Lane flotation and Giemsa staining methods. Furthermore, 10 road-killed hedgehog carcasses were necropsied. The adult parasites were collected and identified under a light microscope.

Results: Spirurida eggs in the stool samples and Anaplasma inclusion bodies in red blood cells were determined in $32 \%$ and $52 \%$ of the samples, respectively. Physaloptera clausa, Mathevotaenia erinacei, Nephridiacanthus major, and Moniliformis moniliformis were identified in the necropsy.

Conclusion: To the best of our knowledge, ours is the first study concerning endoparasites of long-eared hedgehogs in Iran. Furthermore, M. erinacei was for the first time reported as a parasitic fauna in Iran. (Turkiye Parazitol Derg 2016; 40: 37-41)

Keywords: Long-eared hedgehog, endoparasites, Zabol, Iran

Received: 05.10.2015

Accepted: 24.12 .2015

\section{ÖZ}

Amaç: Uzun kulaklı kirpi (Hemiechinus auritus), İran'ın iç bölgelerinde ve güney doğusunda yaşayan noktürnal bir hayvandır. Ancak, İran' daki bu kirpilerdeki, bazıları zoonotik olan endoparazitler hakkında az sayıda çalışma bulunmaktadır. Bu çalışmanın amacı, Güneydoğu İran'ın Zabol bölgesinde yaşayan uzun kulaklı kirpilerde görülen endoparazitleri araştırmaktır.

Gereç ve yöntemler: Toplam 50 canlı kirpiden (35 dişi ve 15 erkek) alınan dışkı ve kan örnekleri, Clayton-Lane flotasyon ve Giemsa boyama yöntemleri ile incelendi. Ayrıca, taşıtların çarptığı 10 kirpi karkası nekropsi yapıldı. Yetişkin parazitler toplandı ve ışık mikroskopu altında incelendi.

Bulgular: Dışkı örneklerinin \%32'sinde spirurida yumurtası ve kırmızı kan hücresi örneklerinin \%52'sinde anaplasma inklüzyon cisimcikleri saptandı. Yapılan nekropside Physaloptera clausa, Mathevotaenia erinacei, Nephridiacanthus major, ve Moniliformis moniliformis bulundu. Sonuç: Bilgimiz kadarıyla çalışmamız, İran'daki uzun kulaklı kirpilerde endoparazitler hakkında yapılan ilk çalışmadır. Ayrıca, M. erinacei bir parazit fauna olarak Iran'da ilk defa rapor edilmiştir. (Turkiye Parazitol Derg 2016; 40: 37-41)

Anahtar Kelimeler: Uzun kulaklı kirpi, endoparazitler, Zabol, İran

Geliş Tarihi: 05.10.2015

Kabul Tarihi: 24.12.2015

Address for Correspondence / Yazışma Adresi: Dr. Reza Nabavi E.mail: nabavi_v_r@yahoo.com DOI: 10.5152/tpd.2016.4541

(CTelif hakkı 2016 Türkiye Parazitoloji Derneği - Makale metnine www.tparazitolderg.org web sayfasından ulaşılabilir. (C) Copyright 2016 Turkish Society for Parasitology - Available online at www.tparazitolderg.org 


\section{INTRODUCTION}

Hedgehog is a small nocturnal mammal that is a member of the Erinaceinae subfamily of the order Erinaceomorpha and has a spiny body and individually characterized feint features $(1,2)$. Their diets involve some foliage, mollusks, earthworms, snakes, and frogs, some of which are intermediate hosts for some of their endoparasites $(3,4,5)$. There are four hedgehog species identified in Iran: the long-eared hedgehog (Hemiechinus auritus), East European hedgehog (Erinacea concolor), desert hedgehog $(H$. oethiopicus), and Brandt's hedgehog $(H$. hymelas) $(1,6)$. There are few scientific studies about the parasitic fauna of hedgehogs in $\operatorname{Iran}(1,2,3,7,8)$. Thus, we aimed to be the first to

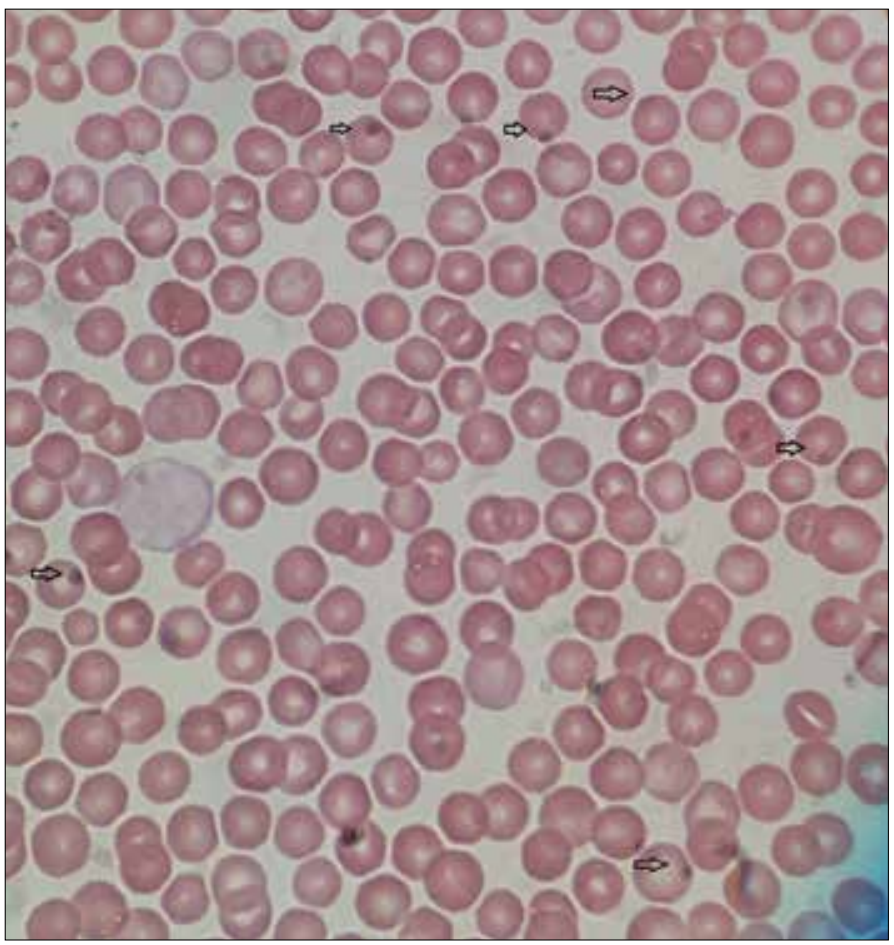

Figure 1. Anaplasma inclusion bodies on the margin of red blood cells
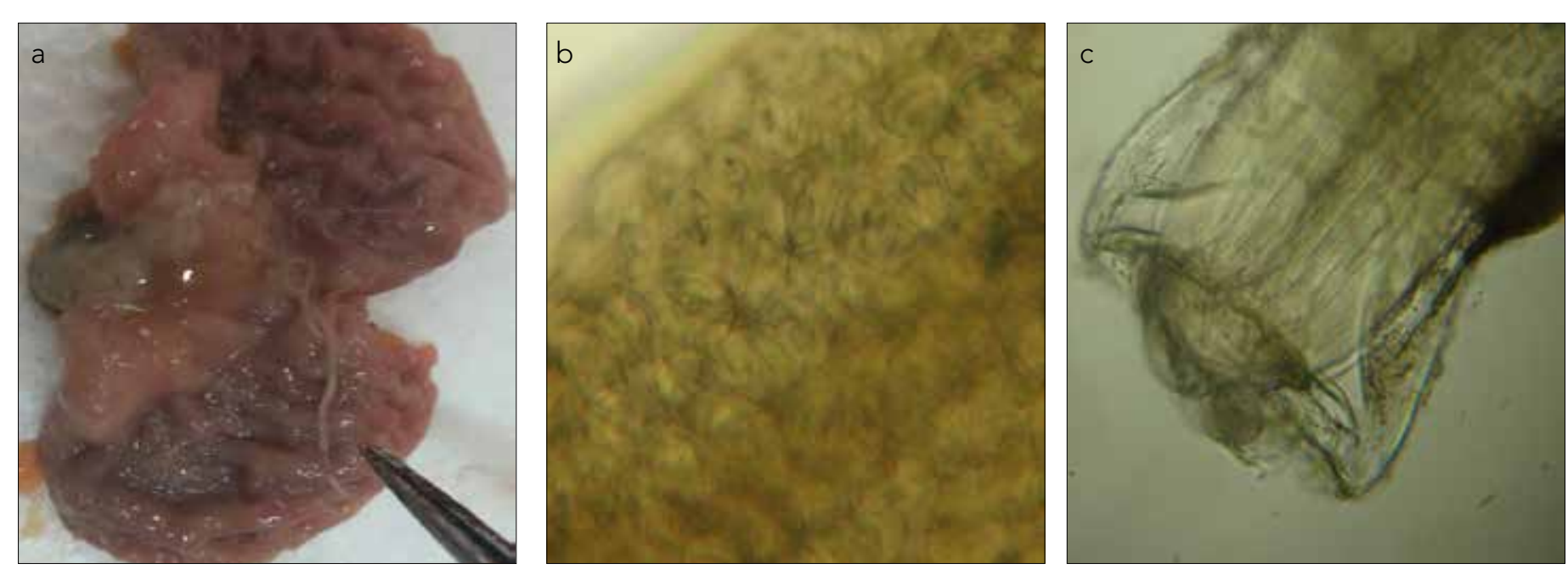

Figure 2. a-c. Adult female Physaloptera clausa. The nematode has been found in the stomach of the long-eared hedgehog (a), plenty of spirurida eggs with first-stage larvae in the uterus (b), the anterior end shows a collar-like projection (c) investigate and present a study on endoparasites in long-eared hedgehogs living in Zabol district, Southeast Iran.

\section{METHODS}

The present survey was performed in Zabol, Southeast Iran from April 2014 to April 2015. The climate of the area is very hot temperate and dry in the summer and mild cold-dry in the winter (9). The parasitological examination procedure of the present study included three steps. First, 50 live adult hedgehogs (35 males and 15 females) were trapped for stool and blood examinations. They were kept in separate cages for a day and their feces were collected. Fecal analysis was performed by the standard Clayton-Lane technique using Sheather's sugar solution $(1,10,11)$. Subsequently, all the hedgehogs were anesthetized with diethyl ether for collecting peripheral blood from their ears (12). From each hedgehog, a thin-layered blood smear was prepared using blood sample from the ear vein. The Giemsa staining was conducted according to Kelly (13) to find blood parasites. The slide was examined under a light microscope with $100 \times$ magnification. The presence of Anaplasma inclusion bodies on the margin of red blood cells confirmed the contamination (14). After recovery, the hedgehogs were released. Following this, 10 road-killed hedgehog carcasses were collected around the district. All of the body organs were separated. The contents of the digestive duct and the mucosa were emptied in hypothermal water for finding helminthes. The stomach, small intestine, and large intestine were removed from the bodies, opened separately, and the helminthes were collected before being fixed in ethanol 70\%. The nematode specimens were cleared in lactophenol on a standard microscope slide; the cestode and achantocephalan specimens were stained with acetocarmine before final identification according to Youssefi (3), Soulsby (15), and Al-zihiry (16). Statistical analysis was performed using SPSS Software (SPSS Inc. Chicago, IL, USA).

\section{RESULTS}

It was found that 16 of the 50 stool samples and 26 of the 50 blood samples were infected with spirurida eggs and Anaplasma spp (Figure 1), respectively. Furthermore, one nematode, Physaloptera clausa (Figure 2), one cestod, Mathevotaenia erina- 

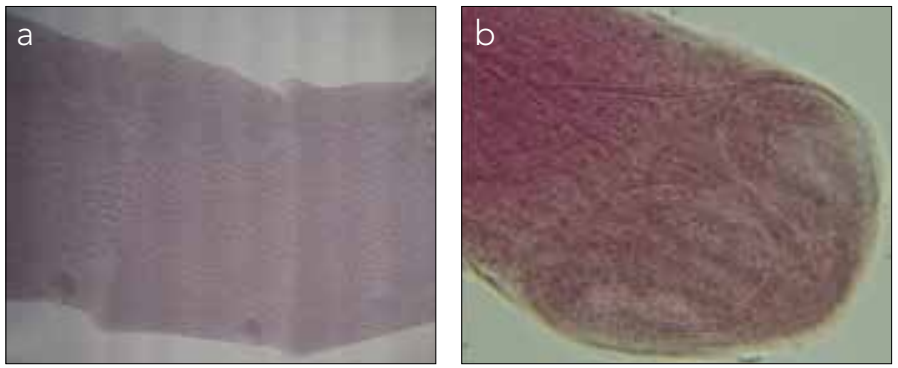

Figure 3. a, b. Mathevotaenia erinacei. The gravid proglottids with irregular alternating genital pores (a), unarmed skolex has four suckers (b)

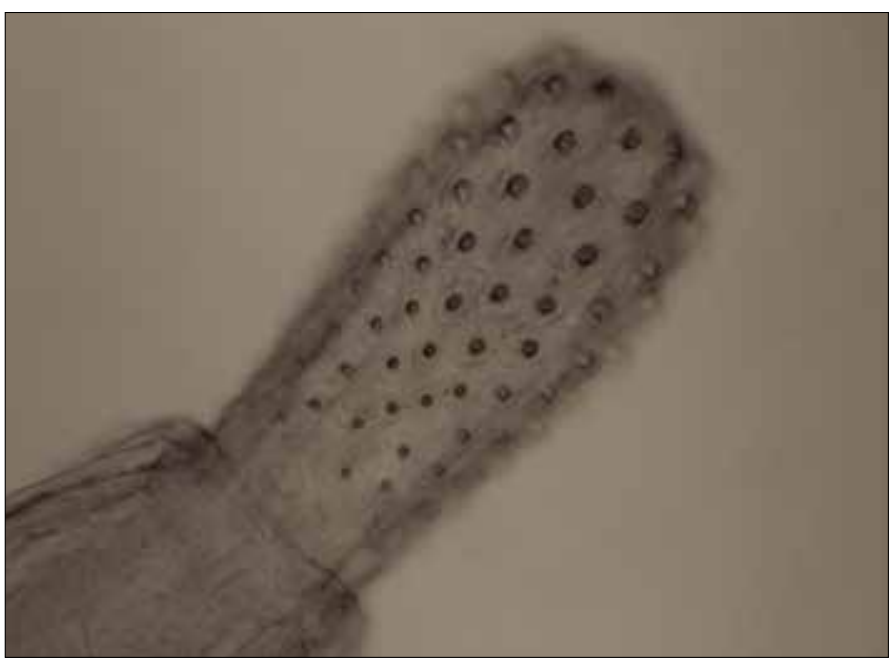

Figure 4. Proboscis of Nephridiacanthus major

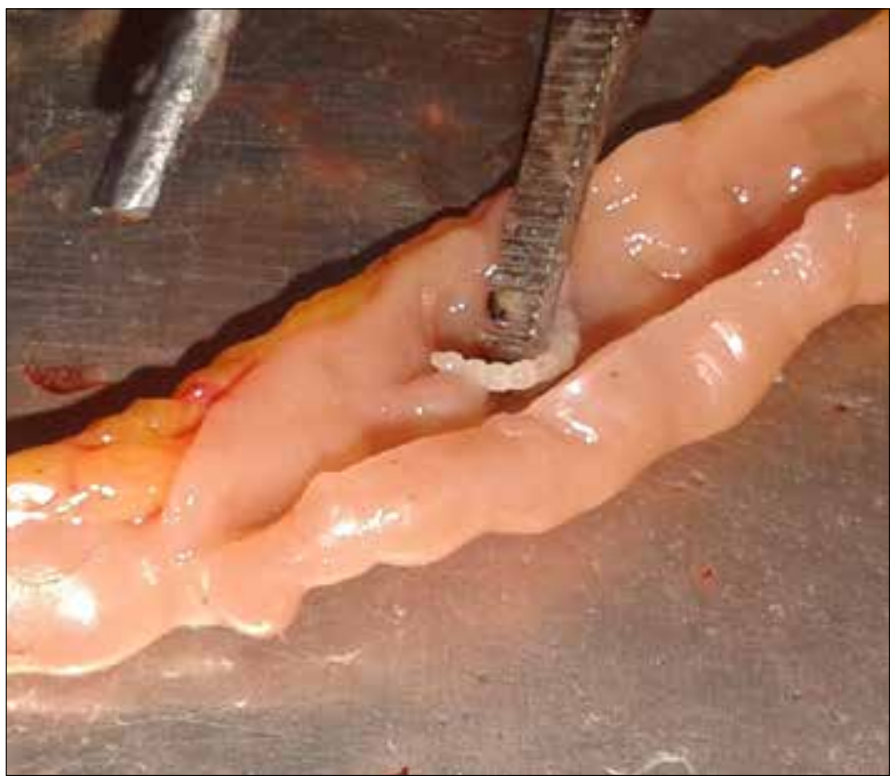

Figure 5. Moniliformis moniliformis attached to the small intestine of a long-eared hedgehog

cei(Figure 3), and two acanthocephala species, Nephridiacanthus major (Figure 4) and Moniliformis moniliformis (Figure 5), were identified in the necropsy (Table 1). The statistical analysis showed no significant correlation between the sex and infection in the hedgehogs.
Table 1. Localization and infection rate of collected parasites from hedgehogs.

\begin{tabular}{|l|l|l|}
\hline Parasites & Location & $\begin{array}{l}\text { Infected } \\
\text { animals/ } \\
\text { examined } \\
\text { animals (\%) }\end{array}$ \\
\hline Spirurida eggs & feces & $16 / 50(32 \%)$ \\
\hline Anaplasma spp & RBC & $26 / 50(52 \%)$ \\
\hline Physaloptera clausa & stomach & $4 / 10(40 \%)$ \\
\hline Nephridiacanthus major & small intestine & $2 / 10(20 \%)$ \\
\hline Moniliformis moniliform & small intestine & $1 / 10(10 \%)$ \\
\hline Mathevotaenia erinacei & small intestine & $1 / 10(10 \%)$ \\
\hline
\end{tabular}

\section{DISCUSSION}

In Iran, epidemiological studies on the parasitic fauna of hedgehogs are scarce and most investigations have been performed on European hedgehogs in the north and northwest of the country. Physaloptera clausa (1, 2), Mullerius capillaries (1), Hymenolepis diminuta (1,3), and Nephridiacanthus spp (3) have been reported by Iranian researchers. There is no available data about parasitic fauna in Iranian long-eared hedgehogs, other than one observation of Crenosoma striatum in the lung of long-eared hedgehogs in the east of Iran (17). Hence, the present study was conducted to identify the endoparasites of long-eared hedgehogs from the Zabol district in Southeast Iran to help understand wildlife parasitic disease and decrease the risk of zoonotic pathogen transmission in the area. One of the simplest and advantageous monitoring methods to find live hedgehog helminths is the use of flotation methods (18). The stool flotation method was used in Iranian hedgehogs in the present study for the first time. The results showed small numbers of spirurida eggs present in their feces, probably belonging to Physaloptera spp. However, the necropsy of 10 road-killed animals showed more kinds of helminths living in the digestive system; however, the worm burden was low, only 1-3 per case. Such few eggs passing from these helminths were undetectable by the flotation method. These results are in contrast with the findings of Gaglio et al. (18), who found numerous types of helminthic eggs in European hedgehogs in Britain using the MC Master Method. The reason for the contrast in results could be related to the different climatic conditions in Iran and Britain and consequently different parasitic burden in wildlife animals. The hedgehogs potentially could be infected with some Rickettsia pathogens $(19,20,21)$. Rickettsiae massiliae has been detected in European hedgehogs from France (22) as well as from African and desert hedgehogs from Algeria $(11,23)$. R. massiliae is a causative agent of spotted fever disease in humans (24). Some Anaplasma species, such as Anaplasma phagocytophilum, have been reported in hedgehogs (Erinaceus roumanicus) from Romania (20).The Giemsa staining technique in the present study showed Anaplasma inclusion bodies in 52\% of hedgehog RBC. This is the first observation of such blood parasites in Iranian hedgehogs. Molecular investigations are highly recommended for finding the species of such pathogens in the area. During the necropsy, our findings revealed that the most prevalent helminth of long-eared hedgehogs was $P$. clausa. This heteroxenous nematode is distributed 
worldwide and has been reported before by Gorgani et al. (2) and Youssefi et al. (3) in European hedgehogs from the north and northwest of Iran. Other investigators in African countries have reported Physaloptera spp as the most prevalent nematode in hedgehogs $(23,25,26,27)$. In the present study, $M$. erinacei (Anoplocephalinae) is first reported in Iran. Previously, this cestode was reported in hedgehogs from Algeria (23) and Iraq (16). Several species of Mathevotaenia were reported before from different kinds of insectivorous mammals, especially rodents, worldwide $(16,28)$.

The presence of N. major and M. moniliformis as Acanthocephalans is confirmed in our study. N. major, reported and described before in Europe (8), Central Asia (8), and Iran (3, 8), was collected from different species of hedgehogs. However, although $M$. moniliformis has been reported from hedgehogs worldwide (11), this study represents the first time observation of the parasite in long-eared hedgehogs in Iran. The finding of this acanthocephalan is of human health interest as this species can cause gastrointestinal diseases in humans (11). As is the case with many investigations worldwide, we found different kinds of heteroxenous helminths in long-eared hedgehogs due to their dietary habits, including mollusks like snail and earthworm, and animals such as snake and frog, where some of these are intermediate hosts for the endoparasites that affect them.

\section{CONCLUSION}

The worm burden of long-eared hedgehogs living in the Zabol district of Iran was mild and did not have a high disturbance effect on their final hosts. Further investigation is highly recommended to explain the Anaplasma spp observed in the present study.

\section{Etik Komite Onayı: N/A}

Hasta Onamı: N/A

Hakem Değerlendirmesi: Dış Bağımsız.

Yazar Katkıları: Tasarım - R.N., N.Z.; Denetleme - R.N.; Yazıyı Yazan N.Z., R.N.

Çıkar Çatışması: Yazarlar herhangi bir çıkar çatışması bildirmemişlerdir.

Finansal Destek: Bu çalışma Zabol Üniversitesi araştırma merkezi tarafından desteklenmiştir.

Ethics Committee Approval: N/A

Informed Consent: N/A

Peer-review: Externally peer-reviewed.

Author contributions: Design - R.N., N.Z.; Supervision - R.N.; Writer N.Z., R.N.

Conflict of Interest: The authors declare that there is no conflict of interest.

Financial Disclosure: The project was funded by University of Zabol research center.

\section{REFERENCES}

1. Nematollah A, Ashrafi Helan J, Golezardy H, Zaboli N, Nouruzi M, Azari M. Parasitic fauna of east European hedgehog (Erinaceus Concolor) and their pathplogical aspects in Iran. Adv Zool Botany 2014; 2: 1-5.
2. Gorgani Firuzjaee T, Pour-Reza B, Naem S, Tavassoli M. ectoparasitic infestations of the European hedgehog (Erinaceus europaceus) in urmia, Iran. Vet Res Forum 2013; 4: 191-4.

3. Youssefi MR, Rahimi MT, Halajan A, Moosapour AA, Nikzad R, Nikzad $M$, et al. Helminth parasites of eastern European hedgehog (Erinaceus concolor) in northern Iran. Iranian J Parasitol 2013; 8: 645-50.

4. McCarthy J, Moore TA. Emerging helminth zoonoses. Int J parasitol 2000; 30: 1351-60. [CrossRef]

5. Riley PY, Chomel BB. Hedgehog zoonoses. Emerg Infect Dis 2005, 11: 1-5. [CrossRef]

6. Ziaie H. A field guide to the mammals of Iran. Department of the Environment, Tehran 1996 (In Persian).

7. Youssefi MR, Rahimi MT, Hosseini SM, Darvishi MM. First report of Rhipicephalus turanicus from hedgehog (Erinaceus concolor) in north of Iran. World J Zoo 2011; 6: 401-3.

8. Heckmann RA, Amin OM, Halajian A, EL-Neggar AM. The morphology and histopathology of Nephridiacanthus major (Acanthocephala: Oligacanthorhynchidae) from hedgehogs in Iran. Parasitol Rel 2013; 112: 543-8. [CrossRef]

9. Mohammadi S, Farahi M, Ganjali M, Koohkan S. Roadkill mortality of long-eared hedgehog Hemiechinus auritus from Zabol, SE Iran 2011; 3: 99-101.

10. Nabavi R, Khedri J, Jahantigh M. High clinical disturbance and mortality in pigeon flocks caused by Hadjelia truncata infection in Sistan, Iran. Turk J Vet Anim Sci 2013; 37: 355-7.

11. Khaldi M, Torres J, Samso B, Miquel J, Biche M, Benyetton M, et al. Endoparasites (helminths and coccidians) in the hedgehogs Atelerix algirus and Paraechinus aethiopicus from Algeria. Afr Zool 2012; 47: 48-54. [CrossRef]

12. Hosni MM, El Maghrbi AA. Ectoparasites infestation of free-ranging hedgehog (Etelerix algirus) in north western Libya. Open Vet J 2014; 4: 12-5.

13. Kelly WR. Veterinary clinical diagnosis. Bailliere Tindall, London 1974: 2: 374

14. Majidiani H, Nabavi R, Ganjali M, Saadati D. detection of Theileria annulata carriers in Holstein-friesian (Bastaurus Taurus) and Sistan (Bos tanrus indicus) cattle breeds by polymerase chain reaction in Sistan region, Iran. J Parasit Dis 2015. [CrossRef]

15. Soulsby EJL. Helminths, Arthropods and Protozoa of Domesticated Animals. Baillier Tindal, London 1982; 303-754.

16. Al-zihiry KJ.K. First record of cestode Methevotaenia erinacei in Long-eared hedgehog Hemiechinus auritus in Basrah province, Iraq. J Thi-Qar Sci 2009; 3: 20-6.

17. Mirzaei Dehaghi M, Fathi S, Norouzi Asl E, Borji H, Radfar MH. First report of Crenosoma striatum and Haemonchus contortus in the long-eared hedgehog (Hemiechinus auritus) in Iran. Turkiye Parazitol Dreg 2014; 38: 255-7. [CrossRef]

18. Gaglio G, Allen S, Bowden L, Bryant M, R.Morgan E. Parasites of European hedgehog (Erinaceus europaceus) in Britain: epidemiological study and coprological test evalution. Eur J Wildl Res 2010; 56: 839-44. [CrossRef]

19. Psaroulaki A, Raqiadakou D, Kouris G, Papadopoulos B, Chaniotis $B$, Tselentis Y. Ticks, tick-born rickettsiae, and Coxiella burnetii in the Greek island of Cephalonia. Ann NY ACad Sci 2006; 1078: 389-99. [CrossRef]

20. Oana DM. Researches regarding ecobiology and epidemiology of hard ticks ixodidae attack-vectors of Lyme disease in Romania. Editura Academiei Republicii Popular Romance, Bucurest 2012; 2-5.

21. Hajipour N, Tavassoli M, Gorgani-Firouzjaee T, Naem S, Pourreza B, Bahramnejad K, et al. Hedgehoges (Erinaceus europaceus) as a source of ectoparasites in Urban-suburban areas of northwest of Iran. J Arthropod-Born Dis 2015; 9: 98-103.

22. Marie JL, Davoust B, Socolovschi C, Raoult D, Parola P. Molecular detection of rickettsial agents in ticks and fleas collected from a European hedgehog (Erinaceus europaceus) in Marseilles, Frence. Camp Immunol Microbial Infect Dis 2012; 35: 77-9. [CrossRef] 
23. Bitam I, Parola P, De La Cruz KD, Matsumoto K, Baziz B, Rolain JM, et al. First molecular detection of Rickettsia felis in fleas from Algeria. Am J Trop Med Hyg 2006; 74: 532-5.

24. Vitela G, Mansueto S, Rolain JM, Raoult D. Rickettsia massilia human isolation. Emerg Infect Dis 2006; 12: 174-5. [CrossRef]

25. Gregory MV. Diseases and parasites of the central African hedgehog Erinaceus albiventris Wagner. Zoologische Beitrage 1981; 27: 205-13.
26. Ikeh El, Anosike JC, Okon E. Acanthocephalan infection in man in northern Nigeria. J Helminthol 1992; 66: 241-2. [CrossRef]

27. Kaikabo AA, Kalshingi HA, Saddiq MD, Muazu A, Gashua IB, Suleiman AB. Detection of helminth parasites of ruminants in hedgehog Alterix albiventris. Nigerian J Parasitol 2007; 28: 129-30.

28. Campbell ML, Gardner SL, Navone GT. A new species of Mathevotaenia (cestoda Anoplocephalidae) and other tapeworms from marsupials in Argentina. J Parasitol 2003; 89: 1181-5. [CrossRef] 